Justin K. Hardin

\title{
Galatians and the Imperial Cult
}

\section{A Critical Analysis of the First-Century Social Context of Paul's Letter}

[Die Galater und der Kaiserkult. Eine kritische Analyse des Paulusbriefes vor dem Hintergrund des sozialen Kontexts im 1. Jahrhundert.]

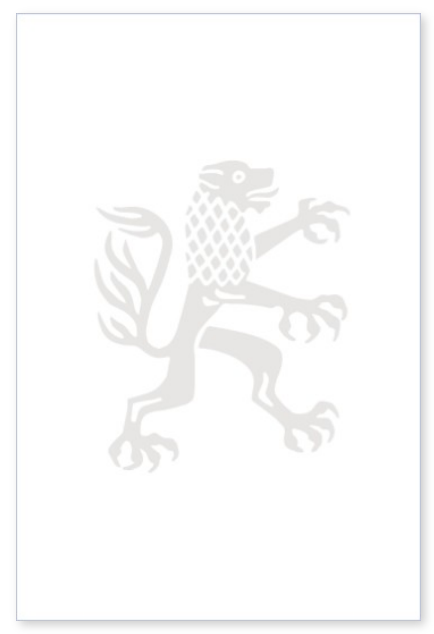

2008. XIV, 190 Seiten. WUNT II 237

ISBN 978-3-16-151580-4

DOI 10.1628/978-3-16-151580-4

eBook PDF 64,00€
Veröffentlicht auf Englisch.

Justin K. Hardin stellt den Kaiserkult als Hintergrund dar, vor dem der soziale Rahmen des Paulusbriefes und der galatischen Gemeinden verstanden werden kann. Er untersucht den Einfluß des Kaiserkults und der imperialen Ideologie während der Julio-Claudianischen Zeit, besonders in der Provinz von Galatien. Anschließend stellt Hardin eine neue Hypothese für die Situation der galatischen Gemeinden auf. Damit leistet er einen wichtigen Beitrag zur anhaltenden Debatte über die Bedeutung des Kaiserkultes für den sozialen und religiösen Hintergrund der neutestamentlichen Zeit.

Justin K. Hardin Born 1976; 2006 PhD at the University of Cambridge; 2004-05 he taught New Testament Greek at Cambridge; since fall 2005 R. Strickland Assistant Professor of Religion at Oklahoma Baptist University (OBU), USA.
Jetzt bestellen:

https://mohrsiebeck.com/buch/galatians-and-the-imperial-cult-9783161515804?no cache=1

order@mohrsiebeck.com

Telefon: +49 (0)7071-923-17

Telefax: $+49(0) 7071-51104$ 